\title{
Edukasi, Pelatihan Evidence-Based Practice In Nursing, dan Evaluasi Pelaksanaan 7 (Tujuh) Benar Pemberian Obat
}

\author{
Sri Rahayu ${ }^{1}$, Melati Fajarini ${ }^{1}$ \\ ${ }^{1}$ Sekolah Tinggi Ilmu Kesehatan Jayakarta, Yayasan PKP DKI Jakarta \\ Email: srirahayu1903@gmail.com
}

Submitted : 06/12/2019

Accepted: 13/12/2019

Published: 31/01/2020

\begin{abstract}
Nursing practice based on scientific evidence or commonly known as Evidence-Based Practice in Nursing is still an interesting trend and issue in Indonesia. This is still something new for nurses because almost the majority of nursing practice based on hospital Standard Operational Procedure (SOP). In fact, the SOP is not all of nursing practice based on scientific evidence. One of the practice of nursing is medication administration which is need to collaboration with the doctor. Therefore, it is necessary to evaluate the administration of 7 (seven) rights of medication. The expected output target is to increase knowledge, and understanding of evidence based practice in nursing in the administration of 7 (seven) rights of medication. The method used education, training, and evaluation of the implementation of 7 rights of medication. The results showed that the majority of nurses had knowledge of 7 rights of medication were $63.3 \%$, and evaluation by direct observations about the implementation of 7 rights of medication were between 50-100\%. Furthermore, nurses are expected to be able to evaluate independently and continuously by using the same minimum method or developing it to get accurate data.
\end{abstract}

Keywords: education, evidence-based practice in nursing, training, 7 rights of medication

\begin{abstract}
Abstrak
Praktik keperawatan berdasarkan bukti ilmiah atau yang biasa dikenal dengan istilah EvidenceBased Practice in Nursing masih menjadi tren dan isu yang menarik di Indonesia. Hal ini masih menjadi sesuatu yang baru bagi perawat pada umumnya karena selama ini hampir mayoritas perawat melakukan praktik keperawatan berdasarkan Standar Operasional Prosedur (SOP) rumah sakit. Kenyataannya SOP tersebut belum semuanya berdasar dari bukti ilmiah. Salah satu praktik keperawatan yang dilakukan yaitu pemberian obat yang merupakan tindakan kolaborasi dengan dokter. Maka dari itu perlu adanya evaluasi tentang pemberian 7 (tujuh) benar obat. Target luaran yang diharapkan adalah peningkatan pengetahuan, dan pemahaman tentang evidence based practice in nursing dalam pemberian 7 (tujuh) benar obat. Metode yang digunakan yaitu dengan edukasi, pelatihan, dan evaluasi tindakan pelaksanaan 7 benar obat. Hasilnya menunjukkan bahwa sebagian besar perawat memiliki pengetahuan tentang 7 benar obat sebesar $63,3 \%$, dan hasil observasi secara langsung tentang pelaksanakan 7 benar obat antara 50-100\%. Selanjutnya diharapkan perawat dapat melakukan evaluasi secara mandiri dan berkelanjutan dengan menggunakan metode yang minimal sama atau mengembangkannya untuk mendapatkan hasil yang akurat.
\end{abstract}

Kata Kunci: edukasi, evidence-based practice in nursing, pelatihan,7 benar obat

\section{PENDAHULUAN}

Evidence-based practice in nursing (EBPN) merupakan konsep yang baru dalam dunia keperawatan. EBPN didefinisikan sebagai penggunaan bukti eksternal, bukti internal (clinical expertise), serta manfaat dan keinginan pasien untuk mendukung pengambilan keputusan di pelayanan kesehatan (Melnyk \& Fineout-
Overholt, 2011). Adapun yang dimaksud dengan bukti eksternal meliputi hasil penelitian, teori-teori yang lahir dari hasil penelitian, pendapat dari ahli, hasil dari diskusi panel para ahli. Sedangkan yang termasuk ke dalam bukti internal adalah penilaian klinis, hasil dari proyek peningkatan kualitas dalam rangka meningkatkan kualitas pelayanan klinik, 
hasil dari pengkajian dan evaluasi pasien, alasan klinis, evaluasi dan penggunaan sumber daya tenaga kesehatan yang diperlukan untuk melakukan treatment yang dipilih, dan mencapai hasil yang diharapkan (Melnyk \& Fineout-Overholt, 2011). Hal tersebut ditujukan dalam rangka memberikan manfaat terbaik untuk kondisi pasien dan menjadi jembatan antara penelitian dan praktik, serta mengeliminasi budaya "practice which is not evidence based".

Praktik keperawatan seharusnya praktik yang berdasarkan bukti. Artinya praktik tidak lagi berdasarkan pengalaman atau kebiasaan semata. Akan tetapi harus berdasar berbasis bukti ilmiah terkini yang dapat dipertanggungjawabkan. Hal ini dimaksudkan untuk mencegah tindakantindakan yang tidak diperlukan atau bahkan merugikan bagi pasien. Maka dari itu menjadi sangat penting untuk memastikan bahwa praktik keperawatan yang dilakukan oleh perawat itu aman. Praktik keperawatan adalah tindakan mandiri perawat professional melalui kerjasama bersifat kolaboratif dengan pasien dan tenaga kesehatan lainnya dalam memberikan asuhan keperawatan sesuai lingkup wewenang dan tanggungjawabnya (Kusnanto, 2004).

Salah satu praktik keperawatan yang dilakukan oleh perawat adalah kolaborasi dalam pemberian obat. Tindakan perawat dalam memberikan obat berdasar pada prinsip benar pemberian obat. Prinsip benar obat berkembang dari tahun ke tahun, yang semula 5 benar, 6 benar, 7 benar, 10 benar, bahkan sampai menjadi 12 benar. Adapun prinsip tersebut disesuaikan dengan kebutuhan rumah sakit, atau minimal rumah sakit mengacu pada 5 benar prinsip pemberian obat.

Hasil studi awal di salah satu rumah sakit tahun 2019 didapatkan data bahwa pelaksanaan 7 benar prinsip pemberian obat masih kurang. Perawat masih melakukan pemberian obat sebagai tindakan yang rutinitas, beberapa ruangan menyiapkan obat dalam satu waktu, dan ada yang terlewat untuk melakukan 7 benar seperti cek nama pasien, cek dosis, cek waktu pemberian. Hal ini perlu mejadi perhatian yang serius dari rumah sakit. Salah satunya adalah dengan memberikan reinformasi kembali kepada perawat dan tanpa lelah kepala ruangan dan ketua tim untuk mengingatkan secara terus menerus.

Penjelasan tersebut diatas menjadi dasar untuk melakukan pengabdian masyarakat melalui metode edukasi, pelatihan untuk mengevaluasi tentang pelaksanaan 7 benar di rumah sakit. Judul pengabdian masyarakat ini adalah "Edukasi, pelatihan Evidence-Based Practice in Nursing, dan evaluasi pelaksanaan 7 (tujuh) benar pemberian obat".

\section{TARGET DAN LUARAN}

\section{Target}

Target kegiatan pengabdian kepada masyarakat ini adalah untuk memberikan pelatihan evidence-based practice in nursing dalam pemberian 7 (tujuh) benar obat. Harapannya adalah dengan memberikan pelatihan, perawat lebih memahami tentang evidence atau bukti ilmiah terkait 7 benar pemberian obat. Selain itu, setelah pelatihan selesai, perawat dapat melakukan evaluasi secara mandiri, berkelanjutan, dan menjadi program rutin dalam meningkatkan mutu pelayanan mutu rumah sakit.

2. Luaran

Luaran kegiatan ini adalah terpublikasinya kegiatan ini dalam jurnal pengabdian kepada masyarakat.

\section{METODE PELAKSANAAN}

Metode pelaksanaan kegiatan pengabdian kepada masyarakat ini dilaksanakan dengan tahapan sebagai berikut:

1. Persiapan

a. Menyiapkan surat undangan

b. Menyiapkan materi 
c. Menyiapkan jadwal kegiatan edukasi, pelatihan, dan evaluasi.

\section{Hari Pertama}

a. Pemberian materi tentang evidencebased practice in nursing.

b. Pemberian materi tentang 7 (tujuh) benar pemberian obat

3. Hari Kedua pelaksanaan 7 (tujuh) benar pemberian obat
a. Persiapan kuesioner evaluasi
b. Pengambilan data
c. Entry data

4. Hari Ketiga
a. Pengolahan data
b. Presentasi hasil

Kegiatan pengabdian kepada masyarakat ini dilaksanakan selama tiga hari yaitu pada tanggal 24-26 Juni 2019 di salah satu rumah sakit.

\section{HASIL DAN PEMBAHASAN Hasil}

Hasil dari kegiatan ini meliputi karakteristik perawat yang hadir dalam kegiatan edukasi, pelatihan, dan evaluasi pelaksanaan 7 benar obat. Selain itu, juga dituliskan hasil pengetahuan perawat tentang 7 benar pemberian obat, dan hasil evaluasi melalui metode observasi dari pelaksanaan 7 benar obat.

\section{Karakteristik Perawat}

Tabel 1. Distribusi Frekuensi Perawat Berdasarkan Umur dan Lama Bekerja $(\mathrm{n}=30)$

\begin{tabular}{lcccc}
\hline Variabel & Min & Maks & Mean & $\begin{array}{c}\text { Standar } \\
\text { Deviasi }\end{array}$ \\
\hline Umur & 23 & 44 & 30,37 & 6,21 \\
Lama & 0,60 & 13,00 & 4,71 & 4,45 \\
Bekerja & & & & \\
\hline
\end{tabular}

Pada tabel 1 menunjukkan bahwa umur perawat minimum 23 tahun, maksimum 44 tahun, dengan rata-rata berusia 30 tahun. Sedangkan lama bekerja perawat minimum 0,60 bulan, maksimum 13 bulan, dengan rata-rata lama bekerja 4,71 tahun.
Tabel 2. Distribusi Frekuensi Perawat Berdasarkan Jenis Kelamin, Pendidikan Terakhir, dan Unit Kerja $(\mathrm{n}=30)$

\begin{tabular}{lcr}
\hline Karakteristik Perawat & Frekuensi & Persen \\
\hline Jenis Kelamin & 17 & $56.7 \%$ \\
Laki-laki & 13 & $43.3 \%$ \\
Perempuan & & \\
Pendidikan Terakhir & 23 & $76.7 \%$ \\
D3 Kep & 2 & $6.7 \%$ \\
S1 Kep & 5 & $16.7 \%$ \\
S1 Kep+Ners & & \\
Unit Kerja & 7 & $23.3 \%$ \\
IGD & 11 & $36.7 \%$ \\
ICU & 6 & $20 \%$ \\
Lotus (NICU) & 6 & $20 \%$ \\
OK & &
\end{tabular}

Pada tabel 2 menunjukkan bahwa sebagian besar perawat memiliki jenis kelamin laki-laki sebanyak 17 orang (56.7\%), berpendidikan D3 keperawatan sebanyak 23 orang $(76.7 \%)$, dan bekerja di ruang ICU sebanyak 11 orang (36.7\%).

\section{Pengetahuan Perawat Tentang 7 Benar} Pemberian Obat

Tabel 3. Distribusi Frekuensi Perawat Berdasarkan Pengetahuan 7 Benar Obat $(\mathrm{n}=30)$

\begin{tabular}{|c|c|c|}
\hline Pengetahuan & $7 \quad$ Frekuensi & Persen \\
\hline
\end{tabular}

\begin{tabular}{llc}
\hline Lengkap & 19 & $63.3 \%$ \\
Tidak Lengkap & 11 & $36.7 \%$ \\
Total & 30 & $100 \%$ \\
\hline
\end{tabular}

Pada tabel 3 menunjukkan bahwa pengetahuan perawat tentang 7 benar obat adalah perawat yang lengkap menuliskan 7 benar sebanyak 19 orang (63.3\%) dan yang tidak lengkap menuliskan 7 benar sebanyak 11 orang $(36.7 \%)$. 
Evaluasi Pelaksanaan 7 Benar Pemberian Obat

Tabel 4. Distribusi Frekuensi Perawat Berdasarkan Evaluasi Pelaksanaan 7 Benar Pemberian Obat (n=6)

\begin{tabular}{lcr}
\hline 7 Benar Obat & Dilakukan & $\begin{array}{c}\text { Tidak } \\
\text { Dilakukan }\end{array}$ \\
\hline Benar Nama pasien & $5(83.3 \%)$ & $1(16.7 \%)$ \\
Benar Obat & $5(83.3 \%)$ & $1(16.7 \%)$ \\
Benar Dosis & $3(50 \%)$ & $3(50 \%)$ \\
Benar Waktu & $6(100 \%)$ & $0(0 \%)$ \\
Benar Rute & $6(100 \%)$ & $0(0 \%)$ \\
Benar Informasi & $6(100 \%)$ & $0(0 \%)$ \\
Dokumentasi & $6(100 \%)$ & $0(0 \%)$ \\
\hline Total & 30 & $100 \%$ \\
\hline
\end{tabular}

Pada tabel 4 menunjukkan bahwa dari 6 perawat yang melaksanakan tindakan pemberian obat kepada pasien, terdapat 1 orang perawat $(16.7 \%)$ yang tidak melakukan prinsip benar nama pasien, 1 orang perawat (16.7\%) yang tidak melakukan prinsip benar obat, dan 3 orang $(50 \%)$ yang tidak melakukan prinsip benar dosis.

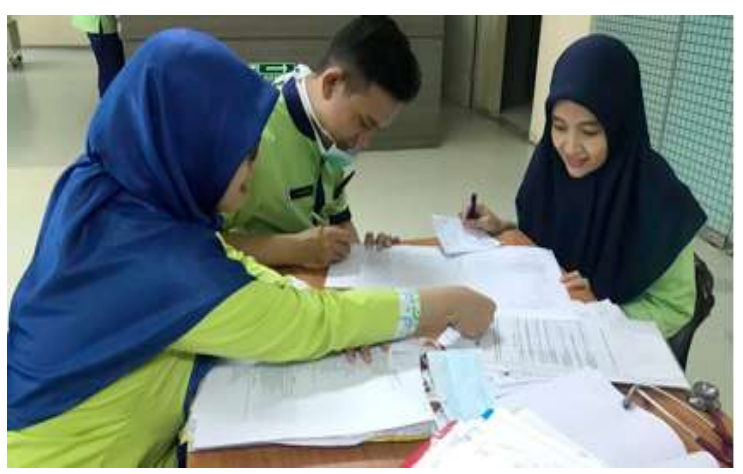

Gambar 1. Latihan Pengambilan Data Dengan Kuesioner

\section{Pembahasan}

Kegiatan pengabdian masyarakat ini sangat menarik hasilnya karena setelah perawat mendapatkan pemahaman akan EBPN dan review kembali akan 7 prinsip benar pemberian obat, perawat yang ikut pelatihan langsung melakukan penelitian secara langsung untuk mengevaluasi salah satu praktik keperawatan yang dilakukan. Perawat yang terlibat untuk pengambilan data tentang evaluasi pelaksanaan 7 benar adalah sejumlah 10 orang. Sedangkan perawat yang terlibat dalam penelitian ini adalah 30 orang perawat yang dinas di ruangan IGD, ICU, NICU, dan OK yang sedang masuk pagi. Kemudian perawat yang memberikan obat kepada pasien adalah sejumlah 6 orang. Hal ini disebabkan oleh waktu pemberian obat sudah terlewatkan yaitu pada jam 09.00 pagi dan waktu pengambilan data baru dimulai di atas jam 10.00 WIB. Akan tetapi hal ini tidak menjadi masalah, karena data yang telah diambil dari 6 orang ini dianggap sebagai sampel acak yang mewakili dari ke-empat ruangan tersebut.

Hasil evaluasi pelaksanaan 7 benar obat yang dilakukan oleh 6 perawat menunjukkan bahwa terdapat 1 orang perawat tidak melakukan prinsip benar nama pasien, 1 orang perawat tidak melakukan prinsip benar obat, dan 3 orang yang tidak melakukan prinsip benar dosis. Identitas pasien merupakan hal yang vital untuk ditanyakan ketika awal kontak dengan pasien. Selanjutnya ketika sudah mengetahui nama pasien, dapat melanjutkan tindakan yang akan dilakukan. Perawat yang dievaluasi tersebut sampai lupa menanyakan nama pasien, bisa jadi karena perawat tersebut sudah hafal dengan nama pasien atau karena memang lupa untuk menanyakan kembali. Sedangkan perawat yang lupa untuk mengecek kembali obat dan dosis karena perawat tersebut kemungkinan disebabkan oleh karena obat yang hendak diberikan sudah disiapkan oleh perawat lain dan sudah diberi label di spuitnya. Akan tetapi hal ini tidak dapat dibenarkan, karena 7 prinsip benar obat terus wajib dilakukan ketika akan memberikan obat kepada pasien untuk menghindari hal-hal yang dapat membahayakan pasien. Hal ini masih analisa sementara, dan perlu penelitian lebih lanjut untuk membuktikannya. 
Hasil penelitian sebelumnya yang dilakukan oleh Kuntarti (2005) menjelaskan bahwa tingkat penerapan enam benar obat oleh 81 perawat RSCM secara umum adalah baik. Tingkat penerapan yang paling tinggi adalah tepat pasien sebanyak 73 orang (90.1\%), selanjutnya tingkat penerapan yang paling rendah adalah tepat dosis sebanyak 11 orang $(13.6 \%)$. Pada penelitian tersebut juga dijelaskan bahwa factor yang mempengaruhi tingkat penerapan enam benar adalah dari faktor internal dan eksternal. Faktor internal meliputi karakteristik perawat dan tingkat pengetahuan perawat. Sedangkan faktor eksternalnya adalah ketersediaan fasilitas pemberian obat, adanya supervise, kebijakan institusi dalam pemberian obat dalam ketersediaan dan penerapan SOP.

Penelitian lain yang dilakukan oleh Anggraini \& Fatimah (2015) menunjukkan bahwa $100 \%$ prinsip benar Rute dan kadaluarsa, 78,5\% prinsip benar pasien, $63,7 \%$ benar obat, $94,1 \%$ benar dosis dan $25,5 \%$ benar informasi. Sedangkan masalah yang didapat dari penerapan 6 prinsip pemberian obat adalah terdapat 6 resep yang diberikan lebih dari dosis yang sebenarnya, tidak tersedianya tempat untuk menyimpan obat-obatan yang telah kadaluarsa, ketidakseimbangan antara apoteker dengan jumlah pasien.

Wahyuni (2015) dalam hasil penelitiannya menambahkan penjelasan tentang adanya korelasi yang rendah antara pengetahuan perawat, perilaku perawat, tindakan perawat dalam penerapan prinsip 6 benar dengan kejadian tidak diharapkan. Sedangkan berkorelasi kuat dengan sikap perawat. Jadi bisa digarisbawahi bahwa sikap perawat sangat berhubungan dengan penerapan prinsip 6 benar.

Hasil penelitian lain yang dilakukan oleh Fatimah (2016) menunjukkan bahwa penerapan prinsip benar yang dilakukan oleh 31 perawat adalah mayoritas kategori cukup sebanyak 19 perawat $(59.4 \%)$ dan yang kategori baik adalah sebanyak 13 perawat $(40.6 \%)$. Kemungkinan hal ini disebabkan oleh karakteristik perawat yang hampir sama dengan usia dewasa muda, mayoritas perempuan dengan pendidikan D3 keperawatan.

Hasil penelitian yang mengejutkan dari penelitian yang dilakukan oleh Mahfudhah \& Mayasari (2018) yang menyebutkan bahwa pemberian obat oleh perawat di RSUD Meuraxa Kota Banda Aceh dengan prinsip 7 benar adalah baik (100\%) yaitu sebanyak 67 perawat yang terlibat dalam penelitian tersebut. Penelitian ini sangat luar biasa hasilnya karena tidak ada kesalahan sedikitpun dalam pemberian obat. Perawat mampu menerapkan prinsip 7 benar pemberian obat. Peneliti tersebut menjelaskan bahwa mayoritas umur perawat pada dewasa awal yaitu 26-35 tahun, pendidikan D3 keperawatan, lama bekerja di atas 10 tahun, dan perawatnya adalah Non PNS. Data ini membuktikan bahwa karakteristik perawat mempengaruhi penerapan prinsip 7 benar pemberian obat.

Maka dari penjelasan tersebut di atas dapat disimpulkan bahwa perlunya manajemen dan pengelolaan rumah sakit secara benar, untuk dapat menghasilkan mutu pelayanan yang berkualitas. Petugas kesehatan terutama perawat dalam hal ini wajib mematuhi SOP dalam melakukan pemberian obat selalu memegang teguh untuk menerapkan prinsip benar obat dengan tepat dan benar setiap harinya. Adapun faktor-faktor yang mempengaruhi pemberian obat dapat menjadi perhatian perawat dalam melakukan praktik keperawatan.

\section{KESIMPULAN DAN SARAN}

\section{Kesimpulan}

Kesimpulan dari kegiatan ini adalah perawat memiliki pengetahuan tentang 7 benar pemberian obat sebanyak $63,3 \%$, dan evaluasi pelaksanaan 7 benar obat adalah pada rentang $50-100 \%$.

\section{Saran}

Ada beberapa keterbatasan dalam kegiatan ini dimana tidak dilakukan 
pre dan post test pada kegiatan edukasi dengan pemberian materi, melatih perawat untuk mengenal penelitian, bukti ilmiah, dan melakukan evaluasi dengan kuesioner. Sehingga target pencapaiannya adalah perawat mampu melakukan penelitian yang sederhana yang sesuai dengan kebutuhan di rumah sakit. Maka dari itu, ke depannya perlu evaluasi pelaksanaan 7 benar obat melalui metode observasi dengan jumlah sampel lebih dari 30 perawat. Selain itu juga diharapkan kegiatan ini menjadi dasar utama dalam melakukan evaluasi secara mandiri, terus-menerus dan berkelanjutkan bahkan hingga menjadi kebijakan rumah sakit setempat.

\section{UCAPAN TERIMAKASIH}

Kami mengucapkan Terima Kasih kepada rumah sakit dan STIKes Jayakarta yang telah memfasilitasi terlaksananya kegiatan ini dengan baik dan lancar.

\section{DAFTAR PUSTAKA}

Anggraini, A. N., \& Fatimah, F. S. (2015). Evaluasi penerapan patient safety dalam pemberian obat di Wilayah Kerja Puskesmas Kasihan II Kabupaten Bantul Yogyakarta. Jurnal Ners dan Kebidanan Indonesia, 3(3), 162-168.
Fatimah, F. S. (2016). Gambaran penerapan prinsip benar pemberian obat di Rumah Sakit PKU Muhammadiyah Yogyakarta Unit II. Jurnal Ners dan Kebidanan Indonesia, 4(2), 79-83.

Kuntarti, K. (2005). Tingkat penerapan prinsip 'enam tepat'dalam pemberian obat oleh perawat di ruang rawat inap. Jurnal Keperawatan Indonesia, 9(1).

Kusnanto. 2004. Pengantar profesi dan praktik keperawatan profesional. Jakarta : Buku Kedokteran EGC.

Mahfudhah, A. N., \& Mayasari, P. (2018). Pemberian obat oleh perawat diruang rawat inap Rumah Sakit Umum Kota Banda Aceh. Jurnal Ilmiah Mahasiswa Fakultas Keperawatan, 3(4).

Melnyk, B. M., \& Fineout-Overholt, E. (Eds.). (2011). Evidence-based practice in nursing \& healthcare: A guide to best practice. Lippincott Williams \& Wilkins.

Wahyuni, R. M. (2015). Perilaku perawat menerapkan prinsip enam benar pemberian obat mencegah kejadian tidak diharapkan (Behavior Nurses In Six Right Principle On Drug Administer With Unexpected Incident). Journals of Ners Community, 6(1), 82-91. 